\title{
Sustainable Rangeland Management, Economic Growth, and a Cautious Role for the SRM
}

\section{By Brian Czech, Rod Heitschmidt, Joel Brown, and Ann Hild}

I nterest in the art and science of rangeland management increased dramatically during the twentieth century and it was out of this interest that the Society for Range Management (SRM) was born. A review of SRM's early policy statements, position statements, and resolutions reveals SRM's focus was on "traditional" range management issues, such as livestock grazing, rangeland inventory, and multiple uses of rangeland resources. As public interest in rangeland management grew, so did the number, breadth, and depth of rangeland management issues. Consequently, SRM has responded to these new challenges and opportunities by adopting additional policy statements that address a wider array of rangeland management issues, such as biological diversity, noxious and invasive weeds, protection of rangeland and open space values, and reauthorization of the Endangered Species Act.

The evolution of SRM policy statements reveals a general concern with the health and sustainability of rangelands, which in turn reflects an overall concern in academia and public life about ecological and economic sustainability. We believe this is an important and appropriate trend, in and out of the SRM. We also believe that the number and diversity of rangeland management issues will continue to increase in concert with increasing demands for rangeland resources, and that public policies facilitating economic growth have the general effect of increasing demands for natural resources derived from rangelands. The objective of this article is to encourage the SRM to begin to address the effects of continued economic growth on rangeland resources.

\section{Economic Growth and Rangelands}

Economic growth is an increase in the production and consumption of goods and services. The simplest way for an economy to grow is for its population to grow. All else being equal-seldom the case but useful for illustration-a doubling of the population results in a doubling of the economy's size. The other basic mechanism for economic growth is when per capita production and consumption grow. This may occur when more hours are spent working; but more important, for the long-term, is new technology, which leads to higher rates of extraction and/or more efficient use of resources. For most nations, economic growth reflects a concurrent increase in population and per capita production and consumption, all facilitated by the development and implementation of new technology.

The size of an economy is indicated by its gross domestic product (GDP). GDP is a simultaneous measure of production, income, and expenditure occurring within designated boundaries during a given time period. It is calculated in terms of the monetary value of final goods and services. For example, a loaf of bread is a final good, whereas wheat is an intermediate good. Only the value of a loaf of bread, as determined by its market price, is accounted for in the calculation of GDP.

As economists and others have often noted, GDP is not necessarily a good indicator of an economy's "health" or vigor, much less an indicator of a community's overall welfare. However, GDP is an excellent indicator of an economy's size. In the United States, for example, GDP has been calculated by the Bureau of Economic Analysis since the early twentieth century, with much attention paid to methodological consistency and accounting accuracy. Such diligence reflects, in part, the nation's historic emphasis on economic growth as a policy goal. Conversely, other measures of economic performance (e.g., Index of Sustainable Economic Welfare) and human well-being (e.g., Genuine Progress Indicator) must be considered to obtain a more holistic vision of any economy.

The economic activities that occur on rangelands, such as livestock production, mining, energy extraction, recreation, and exurban development, represent sectors that tend to grow as an integrated whole with sectors located elsewhere. For example, a miner brings metals into production that, when manufactured into an implement, are used in the handling and transportation of livestock. The miner, factory 
worker, rancher, and trucker each derive an income, part of which may be spent on outdoor recreation and/or the building of a ranchette. In this case, the mining, ranching, building of the ranchette, and part of the trucking occur on rangelands, whereas the manufacturing takes place in a city or suburb (perhaps in the midst of rangelands), and the outdoor recreation may occur on or off rangelands.

In a more general sense, the production of surplus food and raw materials is required for the existence of less essential sectors such as entertainment (including outdoor recreation). This is a matter of common sense but was described long ago by the classical economists beginning with Adam Smith and their predecessors including Francois Quesnay and the physiocrats. Therefore, a growing economy requires more agricultural and extractive production. In other words, economic growth puts increasing pressure on natural resources, upon which the human economy is founded.

Some have proposed that the "information economy" allows us to dematerialize the process of economic growth, unlike the heavy industrial economies of past decades. But today's information economy is distinguished by the volume of information (facilitated especially by computer technology), not by its basic relationship to the other sectors. Thus, if information cannot be employed in the agricultural, extractive, manufacturing, or service sectors, it won't be marketable and won't be relevant to the issue of economic growth. Also, it takes productive, income-generating activity in other sectors for workers and firms to purchase information. In other words, the information economy grows in an integrated manner with the economy at large.

Consistent with the second law of thermodynamics, the law of entropy, no production process is entirely efficient. Therefore, a natural and inevitable byproduct of economic production is waste or pollution. Rangelands may be polluted from economic activities occurring onsite, or from economic activities occurring upwind or upstream. For example, livestock production on rangelands may result in nitrate and phosphate pollution, and mining activities in mountainous areas may release sulfuric acid that trickles into nearby rangelands. Some rangelands serve as deposition sites for low-level radioactive wastes, and municipal wastes from America's east coast are transported thousands of miles for disposal on western rangelands.

Rangelands exhibit a spectrum of resilience to disturbance and pollution, and the level of resilience is determined both by inherent properties (e.g., soil, vegetation, climate) and by the nature of the disturbance. Whatever the level of resilience exhibited by a particular rangeland, economic growth tends to increase the pressures on rangeland ecosystems to produce more goods and services and/or a greater range of goods and services. In the process, rangeland tends to be subjected to more pollution and/or more types of pollution. As new demands on rangeland ecosystems emerge in a growing economy, it is likely that unforeseen threats (including new pollutants) to rangelands will also emerge.
On the positive side, a growing economy tends to provide more fiscal resources, some of which may be used for rangeland management and restoration. However, the prospect of managing and restoring rangelands sufficiently to countervail the negative, degrading pressures of economic growth is unreliable, and the productivity of less resilient ecosystems may be irrevocably reduced.

To conclude this section, the relationship between economic growth and rangelands is complex. There are abundant examples of positive effects of various economic activities on certain rangeland attributes, but at the same time it is not difficult to see the impacts of increasing population and per capita consumption on rangelands. The potential for increasing the positive effects on rangelands of certain economic activities while minimizing the negative effects of broader economic growth depends to a large degree on how technological progress is managed, not only by our profession but by society at large.

\section{Technological Progress}

Even the most optimistic observers do not deny that, all else equal, increasing production and consumption of goods and services conflicts with environmental protection and ecological sustainability. However, "all else equal" ("ceteris paribus" in economics jargon) is a simplistic criterion, and some believe that technological progress, which makes newer production unequal to older, has reconciled or may reconcile the conflict between economic growth and environmental protection.

In economic terms, technological progress refers not only to new technology but greater productive efficiency, or greater output per unit input. However, in economic terms, the inputs and outputs are measured monetarily, so that technological progress amounts to higher profitability. New technologies and higher productivity, at least in financial terms, have characterized economies since the industrial revolution. Some new technologies increase the material and energetic efficiency (as well as the financial efficiency) by which goods and services are produced, but many new technologies are simply designed for explorative or extractive purposes, leading to higher extraction rates with or without gains in material or energetic efficiency.

When applied to rangelands, the implications of technological progress are difficult to interpret. Certainly the production of goods and services on rangelands has increased over time as new production technologies have been developed. For example, road-building and vehicular technological developments have made rangelands more accessible for harvesting resources (such as fence posts and firewood) and for recreational activity. Essentially by definition, if too much harvesting or too much recreation occurs in an area, resources decline in quantity and quality. On the other hand, previously overharvested areas could be left to rest as technology makes additional areas accessible. Ultimately, though, no more areas are left to exploit economically, and natural resources in the opened areas become depleted. 
Some inventory and monitoring schemes intended to track resource trends, such as the National Resources Inventory, indicate stability over large areas for particular soil and vegetation attributes. However, syntheses of rangeland conditions based on a wider variety of values, such as aerial extent, fragmentation, biological diversity, and economic performance, indicate a general loss of rangelands, decreased resilience, and declining expertise for management that is increasing in complexity. No single inventory system or assessment of conditions is sufficient to describe national, much less global, rangeland trends. One salient point, though, is that localized or microeconomic exceptions to global or macroeconomic trends occur. For example, income derived from economic activities that impact one ecosystem may be used to restore part of another ecosystem. Yet much of that income must also be spent on other, nonrestorative activities, such as subsistence and the maintenance of infrastructure. More restoration than degradation from economic activities would seem highly improbable based upon the second law of thermodynamics, which establishes that entropy (disorder and wastage) increases in the process of converting inputs to outputs.

Entropy aside, technological progress is a highly institutionalized process that results from research and development, or "R\&D." Most of the R\&D in the United States is corporately funded with the remaining portion funded largely by governments. The magnitude of corporate $R \& D$ is a function of corporate profits, and the magnitude of government-funded $\mathrm{R} \& \mathrm{D}$ is a function of revenues, primarily individual income and corporate taxes. In other words, $\mathrm{R} \& \mathrm{D}$ is a function of economic activity at current levels of technology. Future R\&D requires economic growth along the way, using a mixture of existing and forthcoming technology. To exacerbate this dilemma, when corporate profits diminish because of environmental policies, corporations may choose to do business elsewhere. Transferring ecological threats to rangelands in other countries is economically efficient but not conducive to rangeland sustainability from a global perspective.

Perhaps it is impossible to rule out any scenario that seems vaguely conceivable. However, based upon principles of ecology and physics, and long-running empirical evidence, how conceivable is it that technological progress may reconcile the conflict between economic growth and rangeland sustainability? Scarcely, in our opinion, unless one redefines economic growth, which hardly seems like a legitimate reconciliation.

The issue of technological progress and sustainability is sometimes framed as an issue of "optimism" vs. "pessimism," or progressive entrepreneurs vs. antisocial Luddites, unfairly and often for political gain. We can appreciate plenty of people, technologies, and economic activities without losing sight of the fact that growing populations and growing economic sectors necessarily encroach upon rangelands, deplete rangeland resources, and pollute rangelands. New technologies can help in some cases, but overall, technological progress is tightly linked with economic growth using existing technology and, as such, cannot be expected to reconcile the conflict between economic growth and rangeland sustainability.

\section{Economic Growth and the Society for Range Management}

The SRM is "the professional scientific society and conservation organization whose members are concerned with studying, conserving, managing, and sustaining the varied resources of the rangelands which comprise nearly half the land in the world," and its mission is "to promote the professional development and continuing education of members and the public and the stewardship of rangeland resources" (http://www.rangelands.org/about_srm.shtml). SRM has approximately 4,000 members from 28 countries. Its members constitute agency professionals, university professors, students, ranchers, and those interested in rangelands. Because the SRM is concerned with the sustainability and stewardship of rangeland resources, and given the conflict between economic growth and rangeland sustainability, we believe the SRM should be increasingly concerned with the issue of economic growth.

We also believe that SRM should exercise caution with this issue. For the most part we SRM members are not economists conversant in macroeconomic theory and its applications. On the other hand, most economists are not conversant in rangeland ecology and management. Economists with natural resource expertise are typically microeconomists with little background in economic growth or macroeconomic policy. Therefore, when it comes to the conflict between economic growth and rangeland sustainability and stewardship, we leave the discussion to others at the peril of our professional mission, because in some academic circles - and more prominently in political and policy circles - the claim is commonly made that there is no conflict between growing the economy and protecting the environment.

This argument often comes up when an economic development is proposed, along with "mitigation" to negate environmental impacts; for example with energy development projects in the remaining intact portions of the North American sagebrush steppe. As we noted above, localized and microeconomic scenarios are sometimes produced to back this "win-win" claim, without due diligence paid to the global and macroeconomic implications. For example, an oil company may create a wildlife watering pond to mitigate the destruction or disturbance of a spring or riparian area in proximity to an oilfield. This may seem like a "nickel one way, half dozen the other" from a perspective of local wildlife seeking water. However, the additional oil extracted then goes on to fuel commercial, recreational, and other activities impacting environments in numerous localities around the world. Pollution from the combustion of the 
additional petroleum also results, including gases that permeate the atmosphere. Yet the "no-conflict" or "win-win" claim holds sway in policy-making because it amounts to the proverbial having our cake and eating it too, a politically attractive concept.

Perhaps the most prudent approach, then, is cautious proactivity. We cannot afford to wash our hands of the issue, nor can we afford to drown ourselves in it. To put this principle into action, we propose that the SRM take a basic position on economic growth.

\section{Positions on Economic Growth}

Positions on economic growth are already adopted by several professional societies with a focus on natural resources, including The Wildlife Society, the American Society of Mammalogists, the Society for Conservation Biology's North America Section, and smaller organizations such as the British Columbia Field Ornithologists. There is also support from a segment of the economics profession as exemplified by the position taken by the US Society for Ecological Economics. However, more unity is required within and among professional societies to develop the widespread societal understanding required for macroeconomic policy reform.

SRM members may rightly ask, "But what macroeconomic policy reform would we propose?" The cautious but proactive approach would lead first and foremost to simply clarifying the trade-offs between economic growth and sustainable rangelands. That alone would be sufficient to generate discussion and exploration of macroeconomic policy adjustments. Those discussions would naturally include monetary policies such as money supplies and interest rates, fiscal policies such as tax codes and government spending, and trade policies adopted to promote economic growth. However, the SRM need not, and probably should not, engage in that level of discussion. The SRM could do its part by helping to initiate the discussion; for example, by clarifying the trade-offs between economic growth and sustainable rangelands for the general public and policy makers.

It is easy to identify problems, yet many people demand simultaneous solutions. We believe an SRM position that describes the trade-offs between economic growth and rangeland sustainability should also identify a basic alternative to economic growth without getting bogged down in details. Because economic growth inherently conflicts with rangeland sustainability, there are but two basic alternatives to alleviate the conflict: economic recession and economic stability. Although recession is actually advocated in some segments of global society-for example, the movement for "La Decroissance" ("de-growth") in France-the cautious approach for a professional society focused on natural resources is to support a path toward stability.

A stable economy in the sense of an economy that is neither growing nor declining is called a "steady state economy," in which the production and consumption of goods and services has stabilized along with human populations. A steady state economy at a sustainable level would, by definition, coexist with rangelands and other types of ecosystems. In the terminology sometimes used in ecological economics, the human economy would be in dynamic equilibrium with the economy of nature. The steady state economy is not yet a household term, but it has been a cornerstone of ecological economics from its inception, with historic roots in the classical economics of John Stuart Mill. SRM could do its part by bringing the steady state economy as a policy alternative into the public's awareness.

The cautious approach would be to avoid advocating a particular type of economic or political system. After all, capitalist democracies and communist dictatorships alike have been pre-occupied with economic growth, all with major impacts on rangelands and other ecosystems. Likewise, most forms of government could pursue the establishment of a steady state economy if citizens and leadership deemed it necessary. A steady state economy is a macroeconomic condition and a policy goal, not a system of political economy.

SRM can and should play a role in increasing public awareness of the trade-offs between economic growth and ecological sustainability without taking a position on how large a national or global economy should ultimately become. The optimum size or growth rate of an economy may only be ascertained by a polity and its citizens in the context of a staggering array of ecological and cultural factors. Certainly, however, one of the factors that needs to be considered is the relationship between economic growth and the environment, including rangeland environments. No organization is in a more appropriate position than the SRM to describe the basic trade-off between economic growth and sustainable rangeland management.

\section{Suggested Reading}

Asafu-Adjaye, J. 2000. Biodiversity loss and economic growth: a cross-country analysis. Contemporary Economic Policy 21: 173-185.

Beduah, D., J. McArthur, E. Durant, and M. FernandezGimenez [comps.]. 2006. Rangelands of Central Asia: proceedings of the conference on transformations, issues and future challenges. Proceedings RMRS-P-39; 27 January 2004; Salt Lake City, UT, USA. Fort Collins, CO, USA: Rocky Mountain Research Station, US Department of Agriculture, US Forest Service. 127 p.

Clausen, R., And R. York. 2008. Global biodiversity decline of marine and freshwater fish: a cross national analysis of economic, demographic, and ecological influences. Social Science Research 37:1310-1320.

Collins, R. M. 2000. More: the politics of economic growth in postwar America. Oxford, United Kingdom: Oxford University Press. 299 p.

Czech, B. 2008. Prospects for reconciling the conflict between economic growth and biodiversity conservation with technological progress. Conservation Biology 22(6) (in press). 
DAly, H. E., AND J. FARLEY. 2003. Ecological economics: principles and applications. Washington, DC, USA: Island Press. $450 \mathrm{p}$.

Dietz, T., E. A. Rosa, And R. York. 2007. Driving the human ecological footprint. Frontiers in Ecology and the Environment 5(1):13-18.

Herrick, J. E. [Ed.]. 2007. Special issue: ecology in an era of globalization. Frontiers in Ecology and the Environment 5(4): 171-228.

National Research Council. 1994. Rangeland health. Washington, DC, USA: National Academy Press. 180 p.

National Science Foundation. 2007. National patterns of R\&D resources: 2006 data update. NSF 07-331. Arlington, VA, USA: Division of Science Resources Statistics, National Science Foundation. 46 p.

Ruttan, V. W. 2001. Technology, growth, and development: an induced innovation perspective. New York, NY, USA: Oxford University Press. 656 p.

Stern, D. I. 2004. The rise and fall of the environmental Kuznets curve. World Development 32:1419-1439.
Wackernagel, M., N. B. Schultz, D. Deumling, A. Callejas Linares, M. Jenkins, V. Kapos, C. Monfreda, J. Loh, N. Myers, R. Norgaard, and J. Rander. 2002. Tracking the ecological overshoot of the human economy. Proceedings of the National Academy of Sciences 99:9266-9271.

(The) Wildlife Society. 2003. The relationship of economic growth to wildlife conservation. Wildlife Society Technical Review 03-1. Bethesda, MD, USA: The Wildlife Society. 22 p.

Authors are Visiting Professor, Natural Resources Program, Virginia Tech National Capitol Region, Falls Church, VA, USA, czech@vt.edu (Czech); Supervisory Range Scientist (retired), USDA-ARS, Fort Keogh Livestock and Range Research Laboratory, Miles City, MT, USA (Heitschmidt); Supervisory Range Scientist, USDA-ARS, Jornada Experimental Range, Las Cruces, NM, USA (Brown); and Professor, Dept of Renewable Resources, University of Wyoming, WY, USA (Hild). 